\title{
Hermann Gottlieb Dohms: \\ um perfil biográfico
}

Martin N. DREHER ${ }^{1}$

R E SU M 0: 0 artigo verifica a inserção de comunidades de descendentes de alemães luteranos no Rio Grande do Sul, entre os fins do século XIX e o Estado Novo, valendo-sedo perfil biográfico deH ermann Gottlieb D ohms, filho de imigrantes radicados no interior gaúcho. A pós estudos teológicos na Europa, retornou ao Rio Grande do Sul, onde exerceu importante ação teológica, educacional e política. Na primeira metade do século XX fundou uma revista, uma escola, e foi destacado teórico da inserção de imigrantes al emães e deseus descendentes na sociedade brasileira. A partir de temática aparentemente circunscrita, 0 artigo aponta para questões que atingem o todo da inserção de imigrantes em um momento histórico marcado pelo fascismo e pelo totalitarismo.

Pa Lav r a S- c h ave : Hermann Gottlieb Dohms; imigrantes alemães; Rio Grande do Sul; Filosofia.

Os estudos relativos à imigração alemã no Rio Grande do Sul, e mormente à contribuição desta imigração para a conformação da vida econômica, política, social ecultural do Brasil estiveram atérecentemente sob o forte impacto dos esforços de Getúlio Vargas e de seus seguidores que buscavam a formação de um Estado nacional. Tais esforços primaram por negar o direito do "outro" à sua língua, seus costumes, sua identidade. Nesse sentido, foram seguidores conseqüentes do pensamento da I lustração, presente no D iretório de Pombal, quando dizia, em 1755, que

[...] sempre foi máxima inalteravelmente praticada em todas as nações que conquistaram novos domínios, introduzir logo nos povos conquistados o seu próprio idioma, por ser indisputável que este é um dos meios mais eficazes para desterrar dos povos rústicos a barbaridade dos seus antigos costumes; e ter mostrado a experiência que ao mesmo passo que 
se introduz neles o uso da língua do príncipe que os conquistou se lhes radica também o afeto, a veneração, e a obediência ao mesmo príncipe. ${ }^{2}$

Combatidas foram, especialmente de 1930 a 1945, mas ainda nos anos subseqüentes, ${ }^{3}$ as tentativas daqueles grupos que buscavam exercitar conscientementesua cidadania, sem no entanto desistirem do legado cultural dos antepassados, designado de "germanidade", "italianidade", "polonidade", etc. Considerados representantes de pensamento "alienígena" não tiveram suas propostas sequer consideradas merecedoras de discussão. Todavia, observando-se a produção intelectual dos imigrantes alemães e de seus descendentes, somenteno Rio Grande do Sul, desde meados da década de 1870 atéo ano de 1938, verifica-se ingente esforço na busca por cidadania inserida na sociedade, na política, na economia, na cultura deste Estado.

A consciência das características próprias e peculiares ao grupo começou a se cristalizar por volta de 1850, quando chegaram ao Rio Grande do Sul os "Brummer", mercenários alemães contratados pelo governo imperial na luta contra Rosas, e que acabaram permanecendo nesse Estado. No seu todo, porém, a germanidadeno Rio Grande do Sul esteve dividida, grosso modo, em três facções: liberais, luteranos e católico-romanos. Na primeira delas, a liderança foi do jornalista e político Karl von Koseritz; ${ }^{4}$ na segunda houve inúmeras lideranças eclesiásticas, destacando-se as figuras de Wilhelm Rotermund e de Hermann G. Dohms; ${ }^{5}$ na terceira destacaram-se sacerdotes jesuítas, merecendo ser nomeados Theodor Amstad ${ }^{6}$ e M ax von Lassberg. ${ }^{7}$ Enquanto 0 grupo em torno de von Koseritz pôde atuar até o final do Império, quando foi alijado da atuação política, ${ }^{8}$ as facções luterana e católica ${ }^{9}$ puderam atuar até os primeiros anos após a Segunda Guerra Mundial.

Restringimo-nos aqui à faç̧ão luterana, aquela que até o presente mais tem sido estudada pela historiografia que se ocupa com o mundo teuto-brasileiro. Seu estudo pode ser dividido em diversos períodos.

No primeiro desses períodos (1824-1864), geralmente designado de congregacional ou pré-sinodal, registrou-se o ingresso de contingentes de imigrantes luteranos das mais diversas regiões e Estados alemães. Foram artesãos, soldados e agricultores. Nas "picadas", organizavam sua sociedade que tinha como centro o templo, a escola e o cemitério. Al- 
guns migravam para centros maiores, onde exerciam o artesanato. Desenvolviam sociedade e cultura próprias, em que as tradições alemãs e principalmente a língua alemã eram preservadas. 0 desenvolvimento econômico acelerado das picadas, graças ao modelo da pequena propriedade rural, permitia o desenvolvimento das regiões norte do Rio Grande do Sul e de Santa Catarina e o de centros urbanos mais antigos, como Porto Alegre. ${ }^{10}$

Por volta de 1860, o grau de desenvolvimento destas comunidades começou a chamar a atenção de Estados europeus, como a Suíça e a Prússia, iniciando-sena Europa uma série de publicações sobreas "colônias alemãs" no Brasil. Em decorrência, a Sociedade M issionária de Basiléia (Suíça) ea I greja Evangélica da Prússia (Berlim) passariam a enviar missionários e pastores para atuar no seio destas colônias que até então, majoritariamente, haviam eleito seu clero em suas próprias fileiras. Em razão da presença dos liberais alemães, chegados na década de 1850, não raro pastores e missionários com eles colidiriam.

0 ingresso de pastores provenientes dos diversos Estados al emães edaSuíça marcou nova fase na história dos luteranos que, sob sua orientação, constituiriam as primeiras estruturas eclesiásticas, geralmente designadas de sínodos $(1868,1886)$. Estas estruturas foram importantes veículos da reivindicação de direitos de cidadania para os luteranos. ${ }^{11}$ H ouve reações a elas no movimento messiânico dos M ucker ${ }^{12}$ enaquelas congregaçõesque preferiram não aderir.13 0 período (1864-1889) foi também marcado pelas primeiras incursões no mundo da política partidária, havendo acentuada preferência pelo Partido Liberal, liderado pelo conselheiro Gaspar Silveira Martins. ${ }^{14}$ Desde 1871, contudo, havia na Europa uma Alemanha unificada, que após a queda do chanceler Bismarck começou a desenvolver agressiva política pangermanista, buscando valer-se também da Igreja Luterana. A postura alemã, vista no contexto da grande expressão econômica já al cançada pelas colônias de descendentes de alemães no Brasil ao final do século XIX, tornou possível entender porque nesse período começava-se a falar insistentemente de um "perigo alemão". ${ }^{15}$

A República Velha (1889-1930) esteve marcada pelo afastamento dos luteranos da vida político-partidária estadual, não porém da municipal. Havia somente um representante luterano no Parlamento rio- 
grandense, Arno Philipp, cooptado por Borges de M edeiros, quejá antes associara as lideranças teuto-católicas do Partido do Centro, integrado ao Partido Republicano Riograndense. Borges de M edeiros tentava obter os votos luteranos, geralmente conferidos aosliberais. 0 afastamento da política partidária não se dava por opção própria, mas era conseqüência da ditadura positivista. ${ }^{16}$ No entanto, 0 afastamento da participação político-partidária não significava abandono da busca por cidadania. Pelo contrário, basta observar o material didático preparado para o uso em escolas comunitárias luteranas para verificar que havia redobrado esforço nesse sentido. Seu método didático-pedagógico seria hoje designado de construtivista. Desde a primeira cartilha, ${ }^{17}$ o jovem luterano era inserido no contexto brasileiro, melhor, rio-grandense.

As ilustrações apresentam pessoas vestindo calça turca, a bombacha. Presentes estão o tamanduá, a laranjeira, a araucária, a palmeira, a arara, a serraria, a figueira, o papagaio. 0 mesmo Wilhelm Rotermund, autor da cartilha mencionada, preparou gramática para o estudo da língua portuguesa ${ }^{18}$ eo instrumental necessário para uma correta pronúncia do idioma falado no Brasil com a "A O rthoepia da Lingua Portugueza em exercícios para as Escolas allemãs no Brazil". ${ }^{19}$ Theodor Grimm publicou Conhecimento do Estado do Rio Grande do Sul. ${ }^{20}$ Neste livro informa os alunos sobre a geografia, a composição populacional, os municípios. Bruno Stysinski elaborou o Esboço da H istória do Brasil. ${ }^{21} \mathrm{H}$ avia também preocupação com a formação contínua do adulto. Por isso, impressiona o conteúdo da publicação de J.Juenemann, Compêndio para as escolas complementares e noturnas bem como para a classe superior das escolas alemãs no Brasil. ${ }^{22}$ Neste livro há materiais sobre história do Brasil, literatura brasileira, lendas e mitos indígenas, economia brasileira, cidadania, indústria, técnica, etc. A preocupação com a cidadania e o preparo para ela fez deRotermund \& Co., em São Leopoldo, a maior casa publicadora de material didático da América do Sul, no período em estudo. ${ }^{23}$

Desde 1919 começou a ter destaque a contribuição, e posteriormente a liderança de Hermann Gottlieb Dohms. Hermann Gottlieb D ohms era natural de Sapiranga, Rio Grande do Sul, onde nasceu a 3 de novembro de 1887. Os pais, Paul Julius Rudolf Dohms e Marie Lydia, nasc. M icus, atuavam desde 1886 naquela localidade, na qualidade de 
pastores e professores. Apóso aprendizado das primeiras letras na escola dirigida pelo pai, em 1897 o jovem Hermann foi levado pelo mesmo até Rio Grande, de onde, confiado à guarda do capitão do M aceió, iniciou viagem à Alemanha, da qual só retornaria em fins de 1913. Jamais reviu o pai, falecido de enfarte a 9 de junho de 1900, em Pelotas.

Hermann Dohmsteve, pois, sua formação quaseque exclusivamente na Alemanha. De 1898 a 1907 estudou em Gütersloh, em instituição da Sociedade M issionária da Renânia, na qual eram abrigados filhos de missionários que atuavam no além-mar. A tenra idade e o internato moldaram sua maneira deser, tornando-o quase “impenetrável”. Em carta de 1913, dirigida à sua noiva M aria Steinsieck, pôde escrever:

Tinha quase 11 anos ao ingressar [na escola de Gütersloh]. Foi bom. Assumi, sem o querer, muito da maneira de ser dos outros, mas logo muito mais sofri a casa e comecei a me tornar autônomo em relação a eles! Tinha minhas próprias aspirações e meus próprios pensamentos. Desde minha confirmação (1903) comecei a odiar muitas coisas e disso resultou amor bastante difuso em relação a coisas distantes, que eu não conhecia, em relação a outro tipo de vida em mim eao redor de mim. Comecei a me tornar crítico em relação ao cotidiano e banal que era aceito pelos outros sem discussão. Disso resultou, então, minha famosa impenetrabilidade e todos os vícios, que eram minhas melhores virtudes! Eles me preservaram para o belo e para a percepção aberta do mundo, desde minha partida de Gütersloh. ${ }^{24}$

Cinco anos antes, em 1908, também escreveria à noiva, dizendo que lhe sobrava pouco tempo para ser "realmente gente":

Sou pessoa terrivelmente dada ao prazer em coisas espirituais. Se possível, colho em todo o lugar apenas as flores, o mais belo e nobre. Satisfazer-me-ia, se qual artista só precisasse assumir a beleza e dar-Ihe nova forma. Procuro também compreender muita outra coisa e jamais consigo, depois, deixá-la; apesar de todo o amor que sinto pelas pessoas verdadeiras, quase não consigo sair de mim. ${ }^{25}$

As expressões, contidasnas formulações do jovem Hermann Dohms são reveladoras eacompanharam por toda a vida. Era pessoa impenetrá- 
vel, mas amava profundamente o esteticamente belo; não conseguia libertar-se de seus objetos, mas dava nova forma aos pensamentos trabaIhados, sabendo dominar admiravelmente a linguagem. Difícil Ihe era demonstrar afeto.

Ao escrever a carta de maio de 1908, encontrava-se em Basiléia, na Suíça. Ao concluir o segundo grau decidira-se pelo estudo da Teologia. Como estava sob forte influência do Pietismo, tinha reservas diante da teologia acadêmica: fogiu das universidades alemãs e inscreveu-se na Escola de Pregadores de Basiléia. Nela estabeleceu contato com a teologia acadêmica, ao freqüentar as preleções de Orelli, M ezger e Wernle. A grande descoberta dessa época foi a teologia deFriedrich Schleiermacher (1768-1834). 0 interesse por Schleiermacher, mas também as influências recebidas de seus professores suíços levaram-no, ainda em 1908, para Leipzig, onde nas aulas de Lamprecht dedicou-se à História da Cultura, e nas aulas de $\mathrm{H}$ auck, à H istória do Dogma.

No ano de 1909, encontramo-lo em Halle, onde deu especial atenção aos estudos de Teologia Sistemática e de Filosofia. Importante foi para ele o encontro com os professores Kähler, Kattenbusch, Loofs e Menzer. Sua atenção maior, porém, esteve dirigida aos pensamentos de M artin Kähler (1835-1912), Albrecht Ritschl (1822-1889) e Ernst Troeltsch (1865-1923). Hermann Dohms aprendeu a questionar como Troeltsch e a responder como Kähler.

Concluídos os estudos, lecionou em Gütersloh, de agosto de 1910 até o final de 1911. Entrementes, na Páscoa de 1911, prestou seu primeiro exame teológico. 0 tempo livre, porém, foi preenchido com estudos filosóficos. Em fins de 1911 passou a freqüentar o Seminário de Pregadores em Soest, na Westfália. A instituição preparava bacharéis em Teologia para o exercício teológico prático. Havia lá também um forte empenho pela Teologia Sistemática. Além disso, Hermann freqüentou o Seminário de Professores da localidade e ampliou seus conhecimentos de música. Duas passagens de cartas à noiva são reveladoras:

Gosto de ser teólogo, mas ainda não percebi que tenha vocação para teólogo prático. ${ }^{26}$

Os jovens algum dia serão meu campo! Penso que tenho realmente 0 dom de lecionar - é verdade que mais para mais velhos do que para a 
juventude no ensino fundamental...! Tenho muita confiança na Providência de que algum dia receberei trabalho do qual entendo eque, entre outras coisas, me dá al egria. ${ }^{27}$

Em Soest, ao que tudo indica, amadureceu seu plano de atuação para o futuro, no Brasil. No ano seguinte esteve em Berlim. Ali trabaIhou com jovens problemáticos, meninos de rua. Ao mesmo tempo, autoridades eclesiásticas alemãs cogitaram em encaminhá-lo aos estudos de pós-gradução. Pensou em dedicar-seaos estudos de Troeltsch. 0 professor-orientador, porém, queria queestudasse John Wiclif. Aos poucos, sepultou o sonho de carreira acadêmica. Em 1913, prestou o segundo exame teológico e retornou ao Brasil no início de $1914 .{ }^{28}$ Em março foi ordenado pastor em Sapiranga, por Wilhelm Rotermund, então presidente do Sínodo Rio-Grandense, e designado com sua esposa para assumir o pastorado em Cachoeira do Sul.

Hermann Dohms retornou ao Brasil marcado pelos 15 anos que passara na Alemanha. Sabia-se ligado à I greja Evangélica na Alemanha, mas ela o decepcionara em um aspecto:

Na I greja Evangélica da Alemanha anterior a 1914 nada me causou maior dor do que o extraordinário distanciamento de sua existência do todo do povo e o silêncio de sua dogmática e de sua ética a respeito da realidade da nação, para a qual eu me dispunha a trabalhar. A ninguém me senti mais ligado do que aos poucos que sabiam o que é nação. Para tanto, sem dúvida, era necessário retroceder a H erder e ao Romantismo e procurar por seus efeitos no presente. ${ }^{29}$

H avia, porém, também decepção em relação aos próprios alemães:

Como alemão do exterior senti com muito maior dor, no Reino Alemão anterior a 1914, o fato de o povo alemão não mais viver na consciência de seus valores imorredouros, mas em um nacionalismo frio, do qual a massa nada mais espera que farta satisfação e a proteção dos interesses materiais. $^{30}$

É inegável que estas afirmações são retrospectivas e formuladas no contexto do primeiro impacto da ascensão nacional-socialista. M as em 
uma de suas cartas à noiva, quando discutiu sedevia permanecer naAlemanha para o doutorado ou retornar ao Brasil, aparece a formulação: “M eu trabalho lá [no Brasil] será belo, porque será maior [ do que na Alemanha], não me prenderá aos limites estreitos de minha comunidade, mas me provocará para fazer algo por toda a germanidade no Rio Grande do Sul". ${ }^{31}$

Na mesma carta podemosler, ainda: "Só quero ser bom colaborador no trabalho, no qual fui posto por nascimento e história [...]".

As experiências feitas na Alemanha e a consciência de ter seu lugar no Brasil parecem ter determinado sua atuação, bem como sua produção intelectual.

Desde sua comunidade, em Cachoeira do Sul, Hermann Dohms começou a influenciar toda a vida do Sínodo Rio-Grandense..$^{32}$ O casionalmente, escrevia no órgão do Sínodo Rio-Grandense, a Folha Dominical. Seguindo a natureza do jornal, os textos tinham caráter de edificação. Faltava-lhe, porém, veículo para o debate de idéias. Foi por isso que começou a editar, desde 28 de abril de 1919, Deutsche Evangelische Blätter für Brasilien (Folhas Evangélicas Teutas para o Brasil). A revista destinava-se a

[...] homens e mulheres que se ocupam com as tarefas que se impõem ao protestantismo teuto no Brasil [pois] o que nos falta é a unidade, não a unidade em novíssimo clube, mas a unidade no sentimento e no pensamento, através da qual surge uma atmosfera intelectual, na qual podemos viver e que, por seu turno, gera vida.

O protestantismo surgido no Brasil através da imigração alemã radicara-se no País, e assim Dohms não teria vida característica própria, não teria objetivos claros: "Não temos ideal enquanto I greja, não temos missão, não temos história e não temos pátria." As palavras provocativas queriam levar a uma discussão que fortalecesse a consciência do mundo protestante de origem teuta quanto à sua origem e a seu futuro. Nos quase vinte anos de existência da revista, foram três os temas de maior abrangência que se destacaram: I greja evangélica, germanidade, Brasil. A revista, porém, foi muito além destas três grandes áreas temáticas. 
As principais discussões teológicas da primeira metade do século $X X$, desde a rejeição do pensamento de Schleiermacher e do Protestantismo Cultural atéa novidade teológica representada por Karl Barth foram trabalhadas. Depois, foi dado destaque aos problemas brasileiros. Todos os temas da política brasileira, questões eclesiais e culturais, bem como temas atinentes às liberdades de consciência, de opinião e de ensino foram abordados. Todas essas temáticas eram perpassadas pelo interesse deinserir os teuto-brasileirosno Brasil, sem quetivessem queabandonar o legado cultural de seus antepassados. Foi esse interesse que 0 motivou a se ocupar com osfundamentos da história e da política brasileiras. Daí resultaram estudos sobre o Positivismo no Brasil, sobre a Constituição do Brasil e do Rio Grande do Sul em particular, sobre os partidos políticos. Todos eles deveriam proporcionar elementosquepermitissem participação conscientedo teuto-brasileiro na vida de seu país, exercício de cidadania. Seus estudos foram na época, sem dúvida, os primeiros estudos interpretativos das doutrinas políticas e partidárias feitos em língua alemã para leitores de língua alemã, mas também os primeiros estudos desta natureza real izados no Brasil.

Dois anos após o início da publicação da revista, Hermann Dohms fundou, a 1 o de julho de 1921, também em Cachoeira do Sul, o Instituto Pré-Teológico. ${ }^{33}$ Com esta escola queria que do seio dos descendentes de imigrantes alemães luteranos saíssem as lideranças eclesiásticas para uma I greja Luterana no Brasil. Na época, quase todos os pastores que atuavam no seio do Sínodo Rio-Grandense eram estrangeiros. M as não foram só pastores os egressos do Instituto Pré-Teológico: gerações de professores universitários e de profissionais liberais passaram pelo IPT, que em 1927 foi transferido para São Leopoldo/RS e instalado no Seminário para a Formação de Professores, no prédio da atual Câmara Municipal de Vereadores. A partir de 1930 a escola teria prédio próprio no bairro Morro do Espelho.

Desde 1914 Dohms começou a trabalhar também pela autonomia do Sínodo Rio-Grandense em relação à I greja Evangélica na Alemanha. Buscou autonomia financeira, autonomia jurídica, e através de nova constituição, a transformação do Sínodo em I greja, parceira de outras denominações. O Sínodo Rio-Grandense passou a ser a I greja Evangélica de Rito Alemão do Rio Grande do Sul. Como existiam na época mais 
três Sínodos no Brasil, formados por descendentes de imigrantes alemães e liderados por pastores vindos da Alemanha, buscou estreitar as relações com eles, tornando seus presidentes co-editores de Deutsche Evangelische Blätter für Brasilien.

O programa acalentado nos anos de estudo na Alemanha, e posto em prática progressivamente desde o retorno ao Brasil, era suportado por concepção teológica que dava sentido às ações. Tal concepção teológica era determinada pela pergunta concernente ao correto relacionamento de Igreja e germanidade, de I greja e comunidade étnica. Para Dohms, etnia era uma ordenação de Deus. Como, porém, sabia que a pluralidade de povos existente não era uma ordenação da criação, "no sentido de uma vontade divina original e definitiva", 34 afirmava que era "uma ordenação do mundo que é, a um só tempo, um mundo do pecado e da graça" (p. 125s). Assim como as demais ordenações de Deus, 0 povo - a etnia - era o âmbito em que o ser humano podia experimentar as realidades de pecado e graça. Era na etnia, no seio de seu povo que 0 ser humano se conscientizava de sua finitude. Perantea sua etnia, perante o seu povo, o ser humano tinha duas opções: podia aceitá-los ou rebelar-se contra eles, negando sua finitude imposta por Deus. Rebelandose, procurando romper essa finitude, o ser humano pode procurar construir "um reino definitivo da humanidade" - eisto seria humanismo -; o ser humano podia ainda situar sua etnia como um valor máximo, negando que ao lado de sua etnia, de seu povo, ainda existiam outros que tinham valor para a humanidade - e chegaria assim ao nacionalismo. Por isso, quando o ser humano se voltava contra a sua finitude, afastava-se de Deus, ficava com seu pecado e o multiplicava. Se, porém, ao contrário, reconhecesse sua finitude étnica como uma ordenação divina, aí adquiriria uma verdadeira existência "desistindo de si mesmo e recebendo-se como graça” (p. 126). Por isso, D ohms pôde afirmar: "Foi o próprio Deus quem atomizou a humanidade, em sua graça, por causa do pecado, em povos, para nestemundo, que ée permanece sendo pecaminoso, onde jamais pode haver uma humanidade, poder levar a seu alvo, o Reino de Deus, que está nos céus."

A partir dessa sua concepção de povos eetnias como ordenações de Deus, D ohms chegou à afirmação de que a fé cristã é uma “visão que vê os povos como uma ordem divina, sem a qual Deus não se tornou, nem 
se tornará, compreensível para nós." É na finitude que Deus se encarna. Dohms só conseguia conceber I greja como I greja que se encarna. Igreja jamais podia ser "I greja mundial ou da humanidade", a não ser que igrejas debasespopulares sereúnissem na unidade deuma confissão. A Igreja que não reconhecesse a limitação imposta por Deus, a limitação étnica, "quererá o ilimitado, o definitivo e se identificará a si mesma com o reino deDeus" (p.127). 0 sentido da história da I greja era para ele: "Individuação do cristianismo, i. é, entrada do Evangelho nas individualidades criadas por Deus, especialmente nesta ou naquela etnia" (p. 128). Essa concepção levou-o a perguntar pelo relacionamento de povo (etnia) e I greja, na história. Para D ohms, onde não havia povo também não poderia surgir I greja, valendo também a recíproca: onde não havia Igreja tampouco poderia surgir povo. Era preciso quea I greja criassepovo onde este inexistia, e por isso povo tinha que ser Igreja. Pois só onde existiam povo e Igreja, o indivíduo e o povo poderiam "compreender-se em sua finitude ... e se saberem portadores de graça divina". Quando é que um povo passa a ser "povo"? D ohms respondeu: "(...) quando não só percebe que, segundo a ordem que Deus estabeleceu para o mundo, devem existir povos, mas quando, além disso, perceber, como povo, em sua história, esta ordem como tal, na qual D eus se Ihe revelou eainda se revela". Um povo é povo no sentido pleno da palavra, quando sabe "que suas limitações Ihe foram impostas por Deus, para que seja um recipiente de sua graça, que não só Ihe perdoa a limitação, mas também a usa como seu instrumento".

Dohms expôs essa concepção, evidentemente influenciado pelo Romantismo de Herder, em época em que o Brasil vivia sob o impacto da Semana de Arte M oderna de 1922, a partir da qual se estava a exigir o caldeamento de todos os grupos étnicos, de todos os "povos" que imigraram para o Brasil. Sabia, no entanto, que existia a possibilidade de assimilação, e era diante dela que afirmava que caso se dissolvessem as bases étnicas do Sínodo Rio-Grandense, "perderíamos, por um tempo indeterminado, a possibilidade de uma compreensão total epura do Evangelho, poiso pleno desdobramento do poder e da compreensão do Evangelho é impossível para o indivíduo, e só se torna possível na família e em seu povo" (p.129). Dohms previa que, com a dissolução das bases étnicas, não haveria por muito tempo um entrosamento com povo, pois 
este inexistiria. Este povo só surgiria após um longo processo biológicosociológico. Essa possibilidade de dissolução das bases étnicas pareciaIhe insuportável por dois motivos: 1ำ, porque o grupo étnico teuto no Brasil pertencia a um povo, "no qual o Evangelho penetrou de forma inigualável" e ao qual foi aberta "a compreensão pura do Evangelho"; 2o, porque, caso viesse a ocorrer a fusão do grupo étnico teuto com outros grupos étnicos no Brasil, isto significaria a inclusão num povo que ainda estava em formação e que, além disso, era católico romano. Aqui, então, a I greja evangélica não mais seria uma I greja de bases populares, pois Ihe faltaria o povo; ela seria apenas uma seita. Por isso, Dohms só via uma saída: ser I greja debases populares eprocurar sêlo sempremais. N esse contexto, a pregação adquiria uma importância vital. A pregação, dizia Dohms, podia ser falsificada em um duplo sentido, deformando o significado da ordenação povo "para a existência da I greja”. A I greja podia servir-se, em sua pregação, de uma deturpação "pietista" do EvangeIho, renunciando, leviana ou inconscientemente, às bases populares. Por outro lado, lançar-se-ia "a uma pregação que liga Evangelho e etnia mui precipitadamente, ou que toma a etnia e sua cultura como conteúdo" (p.131). Para Dohms, essas duas falsas compreensões de pregação não construíam I greja nem mantinham etnia. Somente quando a I greja tivesse uma pregação clara e precisa poderia cumprir com sua missão junto a seu povo. A missão da Igreja junto ao grupo étnico teuto era sua missão eclesiástica. Dohms comentou esta afirmação, ao dizer:

Quanto mais decididamente, como alemães, formos cristãos, - e isso significa: formos seres humanos que reconhecem a ordenação 'povo' como uma ordenação de Deus, relativa ao mundo, para a nossa salvação -, quanto maior for a pureza com que compreen dermos o Evangel ho de pecado e graça, tanto mais profundamente fundamentaremos também as bases étnicas denossa I greja, que [...] tão-somente a partir do EvangeIho podem ser compreendidas e apreendidas corretamente como ordenação divina.

Dohms queria dizer que a I greja "não tem outra coisa a fazer que 'pregar' e 'ensinar' e ocupar-se com 'coisas celestiais'". E, por isso, todo tipo de cultivo de etnia que não consistia no fato de que a missão da 
Igreja junto ao grupo étnico era sua missão eclesiástica, não era uma missão da I greja, mas função do Estado. No entanto, “ondeo Estado não fizer o que lhe cabe por função", ou seja, preservar etnias, a I greja podia vir a assumir esta função (p.132). Para a Igreja valia aquilo que Cristo afirmou a respeito do sábado:

O ser humano não está aí por causa dela, mas ela está aí por causa do ser humano, e ela não pode, partindo de uma compreensão de modo algum 'cristã' de sábado e de I greja, deixar as mãos descansando, em tempo de necessidade, permitindo que seu povo pereça, só porque é 'sábado' ou porque ela é 'Igreja'.

Esse pensamento teológico era o pano de fundo do programa de Hermann G. Dohms. Foi a partir dele que lançou apelos para a criação de um sistema educacional do Sínodo, fortalecendo as escolas comunitárias, fundando o Instituto Pré-Teológico e o Ginásio Teuto-Brasileiro, hoje Colégio Sinodal, em São Leopoldo. Também lançou apelos para a fundação de uma Escola de Teologia que formasse uma classe de pastores, "que esteja familiarizada e ligada com as situações do País e que dêà Igreja, mais e mais o caráter de uma instituição enraizada no povo." 35 Essa reivindicação só veio a se concretizar em 1946. Sua concepção eclesiológica, porém, levou-o a insistir na necessidade de autonomia do Sínodo Rio-Grandense, "uma comunhão que desenvolva e cultive uma vida cultural própria". Autonomia não significava construção de "delimitações espirituais" diante da I greja Evangélica na Alemanha. D ohms queria ver

crescer uma vida espiritual peculiar, na qual se apresenta uma pequena província do protestantismo alemão [...]. Tem que se desenvolver uma formação teuta peculiar, um caráter teuto próprio, caso contrário o declínio écerto. Autonomia significa vida própria e, como não existe vida alheia - vida no sentido pleno. ${ }^{36}$

A busca por autonomia levou a conflitos com setores do governo alemão, representados pelo cônsul Reinhardt, de Porto Alegre. Perante ele, Dohms reagiria: a I greja do grupo étnico teuto no Brasil deveria ter suas bases completamente nesse Estado e ater-se, concomitantemente, 
às peculiaridades culturais desse grupo. Dessa convicção resultou a senha: "Quanto mais brasileiro em questões políticas, tanto mais teuto em questões étnicas!"

Os posicionamentos de Hermann Dohms provocaram muitas discussões. ${ }^{37}$ Em todas elas, porém, manteve linha clara, estabelecendo o quealmejava: uma I greja que, por um lado, preservasse a herança espiritual da Reforma alemã e que, por outro, estivesse inserida no Brasil. Ao concluir, em novembro de 1930, seu estudo sobre O Positivismo no Brasil, diria que o empreendera

[... para que o cidadão brasileiro de origem alemã participe de maneira sempre crescente, com opinião própria, dos acontecimentos políticos de sua pátria. A superação do 'isolamento das populações de origem germânica', da qual fala L. Truda em seu livro sobre a colonização alemã, não através das medidas do governo, mas através do esforço próprio é uma das mais importantes e difíceis tarefas de nossa geração. Ela não será solucionada através de simples participação do 'elemento germânico' na política ou também na luta armada, mas acima de tudo, pela compreensão independente da situação e da tarefa política que é a única que permite que se dê contribuição própria na construção do Estado. ${ }^{38}$

Quando o acusaram de fazer do Sínodo Rio-Grandense um gueto, afirmou: "Nossa I greja terá seus pés no Estado brasileiro ou terá uma existência clandestina, que Ihe preparará seu fim como I greja de bases populares." 39

Foi essa preocupação em ter os "pés no Estado brasileiro" que o levou a produzir uma série de ensaios sobre temas brasileiros. Era necessário que os luteranos brasileiros tomassem real conhecimento das questões candentes do Estado brasileiro. 0 tempo em que os luteranos eram apenas "tolerados" havia seencerrado com a Constituição de 1891; seu comportamento, porém, continuava a ser o dos tempos do Império, quando a cidadania Ihes fora negada. Seu esforço para superar essa situação estava presentenas publicações relativas ao Positivismo, à Constituição, à História dos Partidos Políticos. Passado o interregno do Estado Novo e da Segunda Guerra M undial, esse anseio por integração política e cidadania teve continuidade logo após o final da guerra. Em 1946, em data que não foi possível precisar, Hermann Dohms foi con- 
vencido por lideranças luteranas da necessidade de se reiniciarem os esforços por uma participação política ativa em níveis estadual e federal. Um dos auxiliares diretos de Dohms, Willy Fuchs, viajou pelas comunidades luteranas do Rio Grandedo Sul, exortando os luteranos para que votassem conscientementeem candidatos luteranos. Na Assembléia Legislativa de 1947 encontrava-se, então, como resultado desse esforço, um percentual de deputados com raízes no Sínodo Rio-Grandense que atingia a casa dos $12,7 \%$. Setedos 55 deputados estaduais eram luteranos do Sínodo Rio-Grandense: Hildebrand, Jost, M ichaelsen, Roesch, F.G.Schmidt, Born, Closs; 4 pertenciam ao PSD, 1 ao PTB, 1 à UDN e 1 ao PRP. Para a Câmara dos D eputados foi el eito um representante pela legenda do PTB, Germano Dockhorn. ${ }^{40}$

Desde os primórdios da década de 1930, Hermann G. Dohms viuse exposto a crescente pressão que se expressou em uma série de conflitos, os quais quase levaram ao encerramento das atividades do Sínodo Rio-Grandense. Ao final das discussões, D ohms desistiu de sua concepção de I greja com bases étnicas e da ligação de I greja e germanidade que a ela estava ligada. Essa mudança de pensamento esteve determinada pela crise pela qual Dohmse, com ele, o Sínodo Rio-Grandensetiveram que passar.

Com a ascensão de Hitler ao poder, a 30 de janeiro de 1933, um grupo de pastores alemães radicados no Brasil e com atuação no Sínodo Rio-Grandense veio a se confessar abertamente adepto do nacional-socialismo e do ideário do M ovimento de FéTeuto Cristão. Este movimento unia nazismo e fé cristã, advogava o racismo, com a remoção de todas as influências judaicas, e buscava introduzir o "princípio do Führer" na vida da I greja. Como reação a esse movimento, criou-se um grupo de oposição designado de Grupo de Trabalho da I greja Confessante, que exigia da direção do Sínodo apoio expresso à D eclaração de Barmen. A Igreja Confessantesurgira na Alemanha ainda em 1933, quando cerca de 2.000 pastores protestantes se voltaram contra o "parágrafo ariano", que exigia a exclusão dos descendentes de judeus do seio da I greja Evangélica. $\mathrm{Na}$ Declaração de Barmen foi rejeitada toda e qual quer síntese de fé cristã e nacional-socialismo e proclamada a exclusividade da revelação, assim como ela está contida na Bíblia. ${ }^{41}$ Enquanto nessa discussão havia a possibilidade de cisão no Sínodo, o conflito com o Estado brasileiro punha 
em xeque a existência do Sínodo. Em sua política de nacionalização, o Estado limitava a capacidade de ação da I greja ao exigir o uso exclusivo da língua portuguesa. D epois, à medida que avançavam as tensões da guerra e do envolvimento do Estado brasileiro ao lado dos aliados, a existência física do Sínodo ficaria ameaçada.

0 reerguimento nacional da Alemanha foi entusiasticamente saudado no seio do Sínodo Rio-Grandense em 1933, como de resto em todas as colônias alemãs do Brasil. ${ }^{42}$ Q uão pouco, no entanto, secompreendia o que realmente estava acontecendo na Alemanha fica evidente nas declarações de Hermann D ohms, que via na ascensão deH itler ao poder "uma reviravolta de proporções extraordinárias". ${ }^{43} \mathrm{~A}$ reviravolta ocorrida na Alemanha era vista por el e como uma "revolução" que "não é simplesmente um acontecimento de política [interna] de um Estado". ${ }^{44}$ Ele desconhecia, no entanto, as intenções de Hitler ao dizer: “O movimento na Alemanha proveio da idéia de povo (Volksgedanke), não de um ideal político, eventualmente do ideal do Estado total ou do Führerprinzip na política" (p. 142). Em decorrência desse equívoco, Dohms via a razão histórica efilosófica dessenovo Estado no pensamento dehomenscomo Fichte, Jahn, Schleiermacher e Stein. Tudo o que aconteceu após 30 de janeiro de 1933 na Alemanha foi visto por Dohms como inserido no Volksgedanke. Ele acreditava que o conceito de Estado estava subordinado ao conceito de povo. ${ }^{45}$ Ainda assim, era de opinião que simples mera transferência da revolução nacional alemã para a real idade do grupo étnico teuto no Brasil teria conseqüências catastróficas, pois os pressupostos históricos e sociológicos aqui encontrados seriam de natureza totalmentediversa dosencontradosnaAlemanha. Por isso, volta-secontra as tendências coordenacionistas vindas da Alemanha, que não queriam ver essas diferenças e insistiam em encampar as organizações teutas no Brasil: “N ão destruais com insensatez o que foi criado eo queéportador de um futuro cheio de vida." 46

Para o povo que formava a I greja Luterana no Brasil, a nova ideologia tinha significado, segundo D ohms, no tocante à "realidade povo". O nacional-socialismo teria chegado à conclusão de que o Estado estaria subordinado à etnia e que, portanto, o Estado não poderia criar uma etnia. Além disso, ter-se-ia chegado à conclusão de que a pertença a um Estado e a pertença a um povo não seriam a mesma coisa: 
Doravante, jamais um teuto-brasilei ro poderá lamentar-se, quando lutar por suas instituições culturais e eclesiásticas, como aconteceu no passado, dizendo: A quem pertencemos? Aqui não somos reconhecidos como brasileiros, enquanto não renunciarmos a nós mesmos, e o alemão do Reino, em última análise, também não nos reconhece como alemães. No futuro ninguém poderá tomar por base a política da Alemanha em relação à Polônia para eliminar a escola alemã, como já aconteceu nas lutas pela [preservação da] escola. Esclarecer-se-á, ainda mais que o já ocorrido, o significado da senha por mim formulada há mais de uma década: Quanto mais brasileiro em questões políticas, tanto mais ligado ao povo em questões teutas e vice-versa. Em última análise, não existe outra experiência para o nosso grupo étnico em nosso Estado e, por outro lado, não pode haver nenhuma inserção política sensata no Estado, a não ser com as forças e os dons que nos são peculiares. ${ }^{47}$

Os apelos de D ohms para que as discussões que ocorriam na Alemanha não fossem transferidas para o Brasil não tiveram êxito. Eram trazidas pelos meios de comunicação e por pessoas que migravam. As congregações luteranas tomaram conhecimento de alguns fatos através de revistas e de informações, provindas das I grejas Territoriais Alemãs. Destas igrejas provinham especialmente informações sobre os enfrentamentos no seio das igrejas, e destas em relação ao Estado. Tais enfrentamentos ficaram conhecidos como Kirchenkampf. ${ }^{48} \mathrm{Em}$ breve os pensamentos do M ovimento deFéTeuto-Cristão semanifestariam. ${ }^{49} \mathrm{Em}$ julho de 1933 houve a primeira tentativa de implantar o Führerprinzip na direção do Sínodo, tendo sido feita a exigência de nele se eliminar o "parlamentarismo democrático". N o final destemesmo ano o pastor Erich Knäpper seria designado "dirigente territorial dos Teuto-Cristãos do Brasil". Em maio do ano seguinte, a organização englobava, segundo seu dirigente, dois terços de todos os pastores do Sínodo. Em outubro de 1934, porém, a segunda mais importante força das discussões na Alemanha encontraria partidários no Sínodo. Tratava-se da I greja Confessante, aqui liderada pelo pastor Gustav Reusch. No Concílio Sinodal de 1935, realizado em Cachoeira do Sul/RS, as divergências político-ideológicase teológicas manifestaram-se com toda a força.

Nesse Concílio, Hermann Dohms, que reunia em sua pessoa as funções de editor de revista, diretor do Instituto Pré-Teológico e tesou- 
reiro do Sínodo Rio-Grandense, também foi eleito seu presidente. Sua eleição foi fruto de longas negociações, e se olharmos a composição da diretoria do Sínodo, veremos quão complicada foi. 0 pastor Gustav Reusch foi eleito vice-presidente eo pastor Erich Knäpper, tesoureiro. A convocação de Knäpper para a função de tesoureiro do Sínodo correspondeu aos interesses de D ohms, pois justamente ele poderia ter vindo a ser o homem de maior influência na Diretoria Sinodal por causa do apoio que recebia de fatia considerável dos pastores. Dohms evitou isso, concedendo a Knäpper o posto que antes havia sido seu e do qual Knäpper, sabia-se, nada entendia. Com a eleição de Reusch para vicepresidente, Dohms conseguiu, além disso, ter junto de si o grupo de pastores que se posicionava ao lado da I greja Confessante. Sua habilidade de negociador, mas também sua firmeza evitaram a cisão no Sínodo e, além disso, levaram à dissolução do Pastorado Nacional-Socialista e do Movimento dos Teuto-Cristãos do Brasil. As conseqüências desse Pastorado e do M ovimento, porém, ficariam, efoi Hermann G. Dohms quem teve que enfrentá-las no contexto do Estado Novo. Antes disso, em junho de 1937, exigiria da Igreja Evangélica da Alemanha, da qual eram majoritariamente oriundos os pastores do Sínodo, que reconvocasse três pastores, os quais estavam "provocando considerável inquietação". Na mesma carta solicitou que

[...] investidas de fé teutônica e semelhantes fossem rechaçadas aqui ena Alemanha pelas autoridades competentes. Elas não encontram eco em nossas comunidades e somente aumentam o abismo que infelizmente está se abrindo aqui no país entre alemães do reino e teuto-brasileiros. ${ }^{50}$

Mesmo assim, a influência dos Teuto-Cristãos do Brasil deixou vestígios sensíveis no universo do Sínodo. Nos textos produzidos por teuto-cristãos houve defesa daA lemanha nazista efortes posicionamentos anti-semitas. Além disso, teve grande penetração no meio jovem. ${ }^{51} \mathrm{M}$ ais permanentes porém seriam, a longo prazo, os posicionamentos do pequeno grupo dos partidários da I greja Confessante. Acusavam aqueles cristãos que apoiavam Hitler e que haviam assumido as declarações de Alfred Rosenberg ( $M$ ito do Século XX) de haverem abandonado o que designavam de "cristianismo positivo" ede promoverem a "deificação da 
raça". Assumindo a Declaração Teológica de Barmen, documento básico da I greja Confessante, declaravam que nela "foram reconhecidas e rechaçadas de maneira mais evidente as doutrinas e ten dências de nossa época, estranhas à I greja, e que ameaçam entrar em todas as I grejas nos dois últimos séculos da história da I greja, sob a forma das heresias do secularismo e do sincretismo". ${ }^{2}$ As posições dos adeptos da Igreja Confessante se acirraram quando o Estado alemão e a Direção da I greja Evangélica Alemã intervieram no Seminário da localidade alemã de I Isenburg, do qual número significativo de pastores do Sínodo era egresso. ${ }^{53}$ Em agosto de 1938, também o Grupo de Trabalho da I greja Confessante encerraria suas atividades na área do Sínodo Rio-Grandense.

Como presidente do Sínodo Rio-Grandense, Hermann Dohms manteve posição de reserva diante das discussões alemãs. Em Deutsche Evangelische Blätter für Brasilien publicava, a cada número, resumo das principais discussões em andamento nal grejaalemã. N ão se posicionava, mas apresentava citações dos posicionamentos. N os pou cos comentários que fez, sempre acentuou que a situação na Alemanha não poderia ser suficientemente aquilatada do ponto de vista teuto-brasileiro. M esmo assim, não conseguia crer que a I greja estivesse sendo perseguida na Alemanha, mesmo quando tais perseguições eram descritas na imprensa brasileira. Ainda em 1937 opinava:

Ainda hoje [...] não se trata de as discussões internas da Igreja estarem dirigidas contra o povo ou contra o Estado, nem de o Estado rejeitar a I greja, mas de uma luta, na qual Estado, povo e I greja devem ser levados a uma relação correta. Isso tem que ser dito mais uma vez hoje porque especialmente - mas não só - a imprensa estrangeira - também os jornais brasileiros trouxeram nos últimos dias uma rubrica constante: A perseguição da I greja na Alemanha - muitas vezes reduz as discussões à simples fórmula de que o novo Estado alemão e a Igreja são mundos que se excluem. ${ }^{54}$

Em junho de 1938, o Kirchenkampf foi mencionado pela última vez nas Blätter. Dohms se resignara, definitivamente. Erich Fausel, que acompanhou Dohms durante esses anos, escreveu a respeito:

Agora chegava-se ao ponto em que ele deve ter sentido com crescente clareza que todo o seu ideário acerca da I greja de bases populares estava 
sendo horrivelmente destruído justamente por aqueles que então detinham o poder naAlemanha e que consideravam todo o povo - e com isso também a Igreja - unicamente matéria bruta para seu domínio e planificação de poder. [...] Uma das mais terríveis experiências da vida e do pensamento de Dohms écertamente o fato de haver-se enganado tragicamente quanto à concepção de povo que tinham os homens dirigentes do Estado alemão. ${ }^{55}$

A autocompreensão do Sínodo como I greja de bases étnicas teutas colidiria necessariamente com o nacionalismo brasileiro. Hermann D ohms já o divisava claramente desde 1925. Na época, verificou que o nacionalismo brasileiro era totalmente distinto do europeu. Na Europa, o nacionalismo sefundamentava nos valores do passado, na América do Sul, porém tomava sua substância da esperança no futuro. N esse tipo de nacionalismo orientado no futuro a língua passou a ter significado todo especial. Ela era elemento de ligação em uma nação em formação, na qual os diversos grupos étnicos não tinha passado comum. Quem se ativesseà língua do grupo étnico poderia ser facilmente visto como traidor da pátria. ${ }^{56}$

As transformações ocorridas no Brasil após a Primeira Guerra Mundial não surpreenderam Hermann Dohms. Logo após a Revolução de 1930, constatou quechegavam a seu fim as liberdades concedidas pelo Partido Republicano Rio-Grandense de orientação positivista. Sabia que com o grupo reunido em torno de Getúlio Vargas forças nacionalistas assumiriam o poder eque elas poriam fim ao isolamento do grupo étnico teuto. ${ }^{57}$ Em 1934, temia o que se tornaria realidade em 1937: “Devemos contar no futuro com uma política que se mova em direção ao Estado total eque procurará resolver a questão nacional esocial a partir do Estado por meio de forte política autoritária." ${ }^{58}$ Foi em meio aos prenúncios de uma crise que se preparava que Hermann Dohms foi eleito presidente do Sínodo Rio-grandense, em 1935. Pode-se afirmar que se deve a ele o fato dea crise não haver significado a dissolução dessa I greja.

Instalado o Estado Novo em 10 denovembro de 1937, inicialmente o sistema escolar do Sínodo foi duramente atingido. Dohms instruiu as comunidades luteranas para que as determinações do Estado fossem estritamente obedecidas. Não conseguiu, no entanto, silenciar ante as de- 
mais medidas nacionalizadoras, pois estas atingiam sua Igreja em seu cerne: a pregação. 0 Decreto 1.545, de 25 de agosto de 1939, determinou, em seu artigo 16, que os sermões deveriam ser proferidos em língua portuguesa. A aplicação do decreto ao Rio Grande do Sul, por intermédio do chefe de Polícia do Estado, capitão Aurélio da Silva Py, não conheceu compromissos, como ficou evidente em instruções baixadas a 6 de novembro de 1939. D ohms viu-se forçado a longas negociações expressas em correspondência trocada com o chefe de Polícia..$^{59}$ Foram feitas concessões, mas após o rompimento das relações diplomáticas entre - Brasil e a Alemanha, a 27 de janeiro de 1942, e com a declaração de guerra a 31 de agosto, a situação das comunidades ligadas ao Sínodo se deteriorou rapidamente. A vida da I greja, que se desenvolvera basicamenteem língua alemã, parou. Além disso, os pastoresnão podiam mais transitar livrementepelo Estado: eram estrangei ros. Finalmente, nos anos de 1942/43, muitos pastores foram presos einternados na Colônia Penal Agrícola Daltro Filho, e o próprio Sínodo foi objeto de pesadas críticas e difamações. ${ }^{60} \mathrm{~A}$ situação somente foi amenizada quando os responsáveis pelas ações policiais dos anos de 1938 a 1943 foram afastados de suas funções em setembro de $1943 .{ }^{61}$

Nesse tempo de aflição, D ohms e o Sínodo Rio-Grandensetiveram que refletir a respeito de suas bases e sobre a continuidade das atividades. A continuidade das atividades pastorais foi conseguida através do preparo de jovens estudantes do Instituto Pré-Teológico, enviados para as comunidades, cujos pastores estavam presos ou afastados de suas paróquias em razão de atuarem em áreas de fronteira. Dessa iniciativa resultou a Faculdade de Teologia, instituição que deu origem à atual Escola Superior de Teologia, em São Leopoldo. Mais importante, porém, foi a reorientação filosófico-teológica. 0 resultado de profunda reflexão está expresso em texto publicado por Hermann Dohms no ano de $1948 .{ }^{62}$ Nele se expressa que a tendência de reflexão dominante estava marcada pelo pensamento de Karl Barth e da I greja Confessante. A partir dessa reflexão eraimpossível continuar a compreender o Sínodo Rio-Grandense como Igreja de imigrantes alemães, que deveria ser esteio da cultura germânica. Ela deveria ser, com todas as conseqüências, I greja no Brasil.

Desde o final da guerra, Hermann Dohms passou a intensificar contatos com outros sínodos de descendentes de imigrantes al emães no 
Brasil. Desses contatos e de tratativas surgiu, em 1949, a Federação Sinodal, que poucos anos mais tarde adotaria o nome de I greja Evangélica de Confissão Luterana no Brasil, da qual Hermann Dohms foi o primeiro presidente.

Ao falecer, a 4 dedezembro de 1956, em São Leopoldo, seu currículo indicava que fora pastor (desde 1913), diretor do Insituto Pré-Teológico (desde 1921), presidente do Sínodo Rio-Grandense (desde 1935), fundador do Colégio Sinodal (1936), reitor e professor da Escola de Teololgia (desde 1946), e presidente da I greja Evangélica de Confissão Luterana no Brasil (desde 1950). Sua atuação e seu pensamento foram a expressão da busca por caminho convenientee inserção adequada de parcela significativa dos descendentes de imigrantes alemães no Rio Grande do Sul.

DREHER, Martin N. Hermann Gottlieb Dohms, a biographical profile. História, São Paulo, v. 23 (1-2), p. 133-159, 2004.

A BSTRACT: The article verifies the communities insertion of German Lutherans' descendents in Rio Grande do Sul trough the end of 19th century and Estado Novo, motivated by the biographical profile of Hermann Gottlieb Dohms, son of immigrants settled at the inner of the gaucho state. After his theological studies in Europe, Dohms returned to Rio Grande do Sul, where he had an important theological, educational and political role. During the first half of The $20^{\text {th }}$ century he founded of a magazine, a school and proheminent theoretical of the German immigrants and their descendents' insertion in Brazilian society. Coming up with an apparently circunscript theme, the article points out questions that touch the whole insertion of immigrants in an historical moment which was marked by fascism and totalitarism.

K E Y W o R D s: Hermann Gottlieb D ohms; German immigrants; Rio Grande do Sul; Philosophy.

\section{NOTAS}

1 Professor do Instituto Humanitas da Unisinos - Rio Grande do Sul. CEP 93010020 - São Leopoldo-RS. Martin@bage.unisinos.br 
2 "Directorio que se deve observar nas povoações dos indios do Pará, e M aranhão, em quanto Sua M agestade não mandar o contrario". Lisboa: Officina de Miguel Rodrigues, 1758, p.3. Facsimile em BEOZZO, José Oscar. Leis e Regimentos das M issões. Política indigenista no Brasil. São Paulo: Loyola, 1983.

${ }^{3}$ Cf. SOUZA, José Pereira Coelho de. Caminhada: dois ensaios e outros escritos. Porto Alegre: Globo, 1969.

${ }^{4}$ Cf. OBERACKER Jr, Carlos H. Carlos von Koseritz. São Paulo: Anhembi, 1961; CARNEIRO, José Fernando. Karl von Koseritz. Porto Alegre: Instituto Estadual do Livro, s.d.; GERTZ, RenéE. (org.). Karl von Koseritz. Seleção de textos. Porto Alegre: EDIPUCRS, 1999.

${ }^{5}$ Cf. DREHER, M artin N. I greja e Germanidade. Estudo crítico da História da Igreja Evangélica de Confissão Luterana no Brasil. São Leopoldo: Sinodal, 1984 (2.ed. revista e ampliada. São Leopoldo: Sinodal, 2003).

${ }^{6} \mathrm{Cf}$. RAMBO, Arthur Blasio. 0 Associativismo Teuto-Brasileiro e os primórdios do cooperativismo no Brasil. São Leopoldo: EDUNI-Sul, 1988

${ }^{7}$ Cf. von LASSBERG, Max. Allerlei aus meinem Leben. Porto Alegre: Tipografia do Centro, 1930.

${ }^{8}$ Koseritz foi aprisionado e morreu logo depois; Haensel foi assassinado.

${ }^{9}$ Cf. as contribuições de Arthur B. Rambo, Lúcio Kreutz e Antônio Sidekum in: DREHER, Martin N. (ed.). Populações Rio-grandenses e M odelos de Igreja. São Leopoldo e Porto Alegre: Sinodal e EST-Edições, 1998.

${ }^{10} \mathrm{Cf}$. REINHEIM ER, Dalva Neraci. As colônias alemãs, rios e Porto Alegre. Estudo sobre imigração alemã e navegação fluvial no Rio Grande do Sul (1850-1900). São Leopoldo, 1999. Dissertação de M estrado - UNISINOS, 1999.

${ }^{11}$ Cf. FISCHER, Joachim. Incidente em Santa M aria (Rio Grande do Sul). Estudos Teológicos, São Leopoldo, 27 (3), 1987, p.239-267.

${ }^{12}$ Cf. AM ADO, Janaína. Conflito social no Brasil. A revolta dos Mucker. São Paulo: Símbolo, 1978.

${ }^{13} \mathrm{Cf}$. TEICH M AN N, Eliseu. Imigração e Igreja: As Comunidades-Livres no contexto da estruturação do Luteranismo no Rio Grande do Sul. São Leopoldo, 1996. Dissertação de M estrado - Escola Superior de Teologia.

${ }^{14} \mathrm{Cf}$. DREHER, Martin N . Luteranismo epartici pação política. In: DREHER, Martin N. (org.). Reflexões em torno de Lutero. v.2. São Leopoldo: Sinodal, 1984, p.121-132. ${ }^{15} \mathrm{Cf}$. M OTTER, Ana Elisete. As relações entre as bancadas teuta e luso-brasileira na Assembléia Legislativa Provincial Rio-Grandense (1881-1889). São Leopoldo, 1998. Dissertação de M estrado - UNISIN OS. GERTZ, René E. 0 perigo alemão. Porto Alegre: UFRGS, 1991. 
${ }^{16}$ Cf. PESAVENTO, Sandra Jatahy. História do Rio Grande do Sul. 5äed. Porto Alegre: Mercado Aberto,1990. PESAVENTO, Sandra Jatahy. 0 imigrante na política riograndense, In: LAN DO, Aldair M arli (org.). RS: Imigração eColonização. 2.ed. Porto Alegre: Mercado Aberto, 1992, p.156-194.

${ }^{17}$ ROTERM UND, Wilhelm. Fibel für deutsche Schulen in Brasilien. Neubearbeitet von R. Heuer. 5.ed. São Leopoldo: Rotermund, 1927. A primeira edição data do início do século.

${ }^{18}$ ROTERMUND, Wilhelm. Vollständige Grammatik der portugiesischen Sprache in Regeln und Ü bungsstücken. 7.ed. São Leopoldo: Rotermund, 1925. A primeira edição é de 1897 e em seu prefácio Rotermund escreve: “Em meu entender, é tarefa da escola alemã introduzir as crianças, que se deparam com a língua portuguesa enquanto língua viva e que a aprendem a usar com facilidade, em sua brilhante estrutura, fornecer-Ihes percepção de sua estrutura lógica por meio de regras e de exercícios planejados e capacitá-las a utilizar corretamente esta bela língua, a qual infelizmente é muitas vezes mal falada e escrita." ( $p$. .III).

${ }^{19}$ 10.ed. São Leopoldo: Rotermund, 1908. A Orthoepia tem como mote: "Fallar, escrever e ler devem juntar-se".

${ }^{20}$ GRIM M , Theodor. Heimatkundedes Staates Rio Grande do Sul. Santa Cruz: Stutzer \& Hermsdorf, 1891. 0 lema do livro é "Para amar nossa querência, é necessário conhecê-la".

${ }^{21}$ STY SI N SKI, Bruno. Grundrissder GeschichteBrasiliens. São Leopoldo: Rotermund, s. d. O livro está dedicado a "Sua excelência, o Presidente do estado do Rio Grande do Sul, Dr. Antonio Augusto Borges de Medeiros, o caloroso e ativo promotor das artes e da ciência". Stysinski nomeia "homens representativos para o Brasil": Fernão Cardim, Vicente do Salvador, Antonio Vieira, Gregorio de Mattos Guerra, Eusebio de M attos, Batholomeu Lourenço de Gusmão, José M aurício Nunes Garcia, José da Silva Lisboa ... e muitos outros (p.85-91).

${ }^{22}$ JUENEM ANN, J. Handbuch für Fortbildungs - und Abendschulen sowie für die Oberstufe der deutschen Schulen in Brasilien. São Leopoldo: Rotermund, 1929.

${ }^{23} \mathrm{Cf}$. ainda KREUTZ, Lúcio. M aterial Didático e Currículo na Escola Teuto-Brasileira. São Leopoldo: Unisinos, 1994. Chamo atenção para o jornal didático-pedagógico dos professores luteranos, Allgemeine Lehrerzeitung für Rio Grande do Sul. Vereinsblatt des deutschen evangelischen Lehrervereins in Rio Grande do Sul, publicado de 1901 a 1939.

${ }^{24}$ Carta escrita em Luckenwalde, 20 de junho de 1913. Esta carta e as demais citadas foram colocadas à minha disposição pelo embaixador Gerhard Dohms, em 23 de julho de 1990.

${ }^{25}$ Carta a M aria Steinsieck; Basiléia, 7 de maio de 1908. 
${ }^{26}$ Carta a M aria Steinsieck; Gütersloh, 16 de junho de 1911.

${ }^{27}$ Carta a M aria Steinsieck; Soest, 25 de outubro de 1911.

${ }^{28}$ Os dados acima foram tomados dos CurriculaVitae de Hermann G. Dohms, datados de 3 de dezembro de 1910 e de 1 ㅇ de agosto de 1912 (AKA, Personal-Akten, Arquivo da Igreja Evangélica na Alemanha, Berlim).

${ }^{29}$ Das N eue Deutschland und wir. In: Deutsche Evangelische Blätter für Brasilien 15, 1933, p.98.

${ }^{30}$ Vom völkischen Fühlen zum politischen Bekenntnis - Rede am Deutschen Tag, 18 Januar 1934, in Porto Alegre. In: Deutsche Evangelische Blätter für Brasilien 16, 1934, p.52.

${ }^{31}$ Carta a M aria Steinsieck; Berlim, 27 de dezembro de 1912.

${ }^{32} \mathrm{O}$ período de sua atuação em Cachoeira do Sul foi descrito por ECKERT, Kurt Benno. Quando florescem os arrozais... História da Comunidade Evangélica de Confissão Luterana de Cachoeira do Sul. Porto Alegre: Martins Livreiro, 1994, p.35-42.

${ }^{33}$ DROSTE, Rolf (Org.). Instituto PréTeológico.Uma Escola Singular. São Leopoldo: Sinodal, 1997.

${ }^{34}$ Volk und Kirche. Gedanken zur theologischen Begründung volkskirchlicher Arbeit. In: Deutsche Evangelische Blätter für Brasilien 16, 1934, p.125. M esmo tendo sido publicado em 1934, o texto é resumo de pensamentos formulados desde 1919. ${ }^{35}$ Von einer Theologischen Schule in Brasilien. In: Deutsche Evangelische Blätter für Brasilien 2, 1920, p.93.

${ }^{36}$ D.Dr. Rotermund und die neuere kirchliche Entwicklung in Rio Grande do Sul. In: Deutsche Evangelische Blätter für Brasilien 5, 1923, p.154.

${ }^{37}$ Cf. DREHER, Martin N. I greja e Germanidade. Estudo Crítico da História da I greja Evangélica de Confissão Luterana no Brasil. São Leopoldo, Porto Alegre, Caxias do Sul: Sinodal, EST, EDUCS, 1984, p. 120-125.

${ }^{38}$ Cf. Idem, (org.). Hermann Gottlieb Dohms. Textos Escolhidos. Porto Alegre: EDIPUCRS, 2001, p. 131.

${ }^{39}$ Zur kirchlichen Lage. In: Deutsche Evangelische Blätter für Brasilien 16, 1934, p.64. ${ }^{40}$ Idem, Luteranismo e Participação Política. In: (ed.). Reflexões em torno de Lutero. v.2, São Leopoldo: Sinodal, 1984, p.121-132.

${ }^{41} \mathrm{Cf}$. Idem, A Igreja no Contexto Latino-Americano. São Leopoldo: Sinodal, 1999, p. 180-182.

${ }^{42}$ Cf. Idem, Igreja e Germanidade. São Leopoldo: Sinodal, 1984, p.126s.

${ }^{43}$ Cf. o artigo A Nova Alemanha e Nós. In: DREHER, Martin N. Hermann Gottlieb D ohms. Textos Escolhidos. Porto Alegre: EDIPU CRS, 2001, p.225-236. 
${ }^{44}$ Neuer Zusammenklang. In: Deutsche Evangelische Blätter für Brasilien 13, 1933, p.141.

45 “I sso, pelo que a 'germanidade no exterior', qual seja os grupos étnicos teutos que não possuem a cidadania alemã, há muito tempo luta e líderes teuto-brasileiros há anos basicamente defendem, foi reconhecido em nosos dias na Alemanha pelo alemão de fronteira Adolf $\mathrm{H}$ itler, entre cujos colaboradores se encontra um númnero extraordinariamente grande de alemães do exterior." (idem, p.144) "Compreendei que é a partir do poderoso sentimento de pertença a sua nação que nesses dias se constrói um Reino Alemão que é a vera e defesável expressão da nação, à qual também vós pertenceis." (D o sentimento nacional à confissão política. Cf. também a tradução em DREHER, M artin N. Hermann Gottlieb Dohms. Textos Escolhidos. Porto Alegre: EDIPUCRS, 2001, p.237-245).

${ }^{46}$ A Nova Alemanha e Nós, in: DREHER, Martin N. Hermann Gottlieb Dohms. Textos Escolhidos. Porto Alegre: EDIPUCRS, 2001, p. 229.

${ }^{47}$ Neuer Zusammenklang. In: Deutsche Evangelische Blätter für Brasilien. 15, 1933, p.145.

${ }^{48}$ Cf. DREHER, M artin N. A Igreja Latino-Americana no Contexto M undial. São Leopoldo: Sinodal, 1999, p.177-184.

${ }^{49}$ Cf. para o que segue DREHER, Martin N. I greja e Germanidade. São Leopoldo: Sinodal, 1984, p.130-149.

50 Carta de 9 de junho de 1937 ao Departamento para o Exterior da Igreja Evangélica da Alemanha. Arquivo da Igreja Evangélica na Alemanha - Berlim (AKA, C VII 4).

${ }^{51}$ Veja-se a esse respeito DREHER, M artin N. Op.cit., p.142-148.

${ }^{52}$ Gustav Reusch, Vorschläge zu befriedigender Lösung des Problems 'Ilsenburg". Arquivo da I greja Evangélica na Alemanha, Berlim (AKA, C VI 1 e).

${ }^{53}$ Cf. DREHER, M artin N. O p. cit., p.149-161.

${ }^{54}$ Politische Berichterstattung über die Kirche in Deutschland. In: Sonntagsblatt der Riograndenser Synode. 50, n.37, 1936, p.3.

${ }^{55}$ FAUSEL, Erich. Präses D. Dohms. São Leopoldo: Sinodal, 1961, p.42.

${ }^{56}$ Quais as possibilidades de minorias étnicas na América do Sul?, in: DREHER, Martin N. (org.). Hermann Gottlieb Dohms. Textos Escolhidos. Porto Alegre: EDIPUCRS, 2001, p.213-224.

${ }^{57}$ Os partidos políticos no Rio Grande do Sul no contexto da história política do Brasil, in: DREHER, Martin N. (org), Op. cit., p.128.

${ }^{58} 0$ movimento integralista., in: DREHER, Martin N. (org.). O p.cit., p.267. 
${ }^{59}$ Cf. Correspondência com Aurélio da Silva Py, in: DREHER, Martin N. (org.). O p. cit., p.275-286.

${ }^{60}$ Cf. DREHER, Martin N. I greja e Germanidade. São Leopoldo 1984, p.164-176; . O Estado Novo e a Igreja Evangélica Luterana. In: MÜLLER, Telmo Lauro (Org.). N acionalização e Imigração Alemã. São Leopoldo: U NISIN OS, 1994, p. 87110; PY, Aurélio da Silva. A 5a. Coluna no Brasil. A Conspiração Nazi no Rio Grande. do Sul. Porto Alegre: Globo, 1942. Cf. DREHER, M artin N . (org.). Hermann Gottlieb D ohms. Textos Escolhidos. Porto Alegre: EDIPUCRS, 2001, p.275-286.

${ }^{61}$ Cf. Diário da Assembléia Legislativan.44, de26.6.1950 (texto em PETRY, Leopoldo. 0 125을 Aniversário da Colonização Alemã no Rio Grande do Sul. São Leopoldo; Rotermund, 1950).

${ }^{62}$ Cf. A doutrina da Palavra de Deus e a Pregação, in: DREH ER, M artin N. (org.). Hermann Gottlieb Dohms. Textos escolhidos. Porto Alegre: EDIPUCRS, 2001, p.287-311.

Artigo recebido em 10/2003. Aprovado em 06/2004. 